\title{
Factors associated with the development of diabetes mellitus in older caregivers
}

\author{
Fatores associados ao desenvolvimento de diabetes mellitus em idosos cuidadores \\ Factores asociados al desarrollo de diabetes mellitus en ancianos cuidadores
}

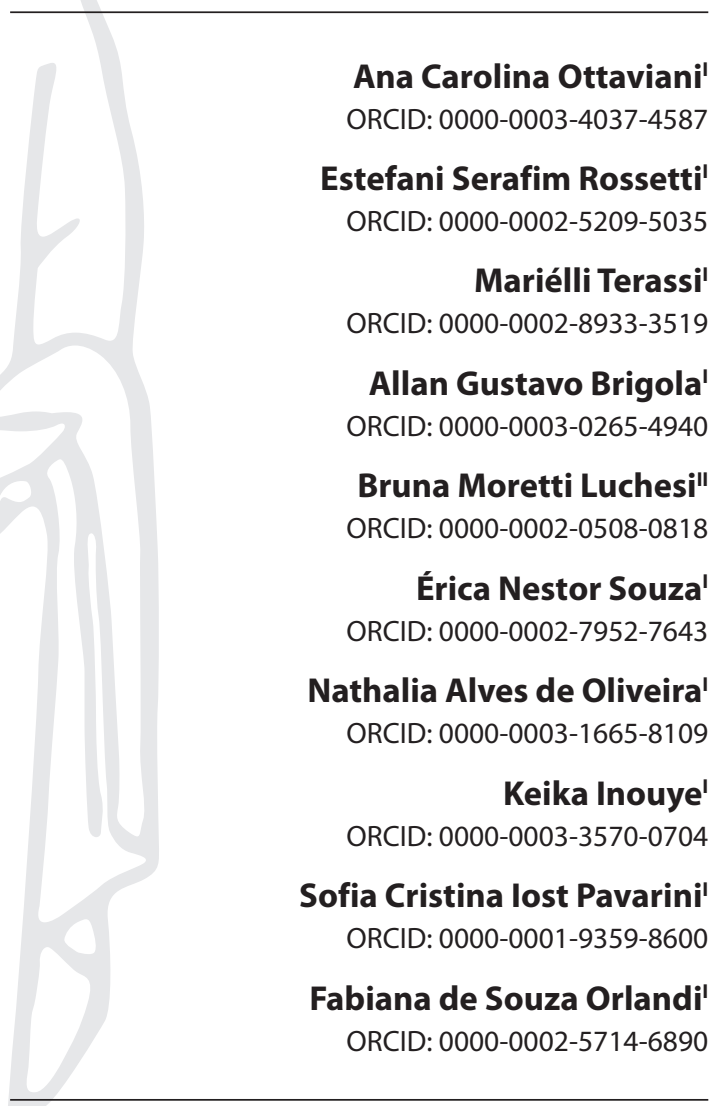

'Universidade Federal de São Carlos. São Carlos, São Paulo, Brazil. "Universidade Federal de Mato Grosso do Sul. Três Lagoas, Mato Grosso do Sul, Brazil.

How to cite this article: Ottaviani AC, Rossetti ES, Terassi M, Brigola AG, Luchesi BM,

Souza EN, et al. Factors associated with the development of diabetes mellitus in older caregivers.

Rev Bras Enferm. 2019;72(Suppl 2):30-5. doi: http://dx.doi.org/10.1590/0034-7167-2017-0590

\author{
Corresponding Author: \\ Fabiana de Souza Orlandi \\ E-mail: forlandi@ufscar.br
}

\begin{abstract}
Objective: evaluate the factors associated with the risk of diabetes mellitus in older caregivers. Method: this is a cross-sectional study conducted with 326 older caregivers enrolled in Family Health Units. Data were collected using a sociodemographic characterization questionnaire, clinical and care information, and the Finnish Diabetes Risk Score to assess the risk of developing diabetes. Results: $35.5 \%$ of the caregivers presented a high risk of developing diabetes. The factors associated with the risk of developing diabetes were: use of medication $(O R=3.88)$, satisfactory or poor health assessment ( $O R=1.72$ ), and the fact of being female ( $O R=0.48)$. Conclusion: more than one third of older caregivers present high risk of developing diabetes. Therefore, being female, living with other people, using medication, and having a poor health assessment are factors associated with increased risk of developing diabetes.

Descriptors: Caregivers; Aging; Health of the Elderly; Primary Health Care; Disease Prevention.
\end{abstract}

\section{RESUMO}

Objetivo: avaliar os fatores associados ao risco de diabetes mellitus em idosos cuidadores. Método: trata-se de um estudo transversal, realizado com 326 idosos cuidadores cadastrados em Unidades de Saúde da Família. Para a coleta de dados utilizou-se um questionário de caracterização sociodemográfica, informações clínicas e do cuidado, e o Finnish Diabetes Risk Score para a avaliação do risco de desenvolvimento de diabetes. Resultados: dos cuidadores, $35,5 \%$ apresentaram alto risco de desenvolvimento de diabetes. Osfatores associados ao risco de desenvolvimento foram o uso de medicamentos $(\mathrm{OR}=3,88)$, a avaliação da saúde regular ou negativa $(\mathrm{OR}=1,72)$ e ser do sexo feminino $(\mathrm{OR}=0,48)$. Conclusão: mais de um terço dos idosos cuidadores apresentam alto risco de desenvolvimento de diabetes. Portanto, ser do sexo feminino, residir com mais pessoas, fazer uso de medicamentos e ter uma avaliação negativa da saúde são fatores associados ao aumento desse risco.

Descritores: Cuidadores; Envelhecimento; Saúde do Idoso; Atenção Primária à Saúde; Prevenção de Doenças.

\section{RESUMEN}

Objetivo: evaluar los factores asociados al riesgo de diabetes mellitus en ancianos cuidadores. Método: se trata de un estudio transversal, en el cual participaron 326 ancianos cuidadores registrados en Unidades de Salud de la Familia. Se utilizó en la recolección de datos un cuestionario de caracterización sociodemográfica, de informaciones clínicas y del cuidado, y en la evaluación del riesgo de desarrollo de la diabetes el Finnish Diabetes Risk Score. Resultados: el 35,5\% de los cuidadores presentaron un alto riesgo de desarrollo de diabetes. Los factores asociados al riesgo de desarrollo fueron: el uso de medicamentos $(\mathrm{OR}=3,88)$, la evaluación de la salud como regular o negativa $(\mathrm{OR}=1,72)$ y ser del sexo femenino $(\mathrm{OR}=0,48)$. Conclusión: más de un tercio de los los ancianos cuidadores presentaron un alto riesgo de desarrollo de diabetes. Por lo tanto, el hecho de ser del sexo femenino, residir con más personas, hacer uso de medicamentos y tener una evaluación negativa de la salud son los factores asociados al aumento de ese riesgo. Descriptores: Cuidadores; Envejecimiento; Salud del Anciano; Atención Primaria de Salud; Prevención de Enfermedades. 


\section{INTRODUCTION}

Brazil sees now a moment of demographic transition due to the fast and intense increase of the elderly population and changes in the epidemiology of the diseases from infectious to noncommunicable (or chronic) diseases ${ }^{(1)}$. Chronicity of health problems and longevity of the population help increase the number of elderly people with impaired function, who then require a caregiver ${ }^{(2)}$.

Most caregivers are family members, providing care in informal environments ${ }^{(3)}$, an intense task that causes several changes in the daily life of caregivers, especially if they are also elderly. Some studies highlight an increase in the number of older people who are informal caregivers of other elderly people with more serious health problems ${ }^{(2,4)}$.

The task of being a caregiver can bring benefits and positive results, but the literature highlights the prevalence of overload or burden due to emotional stress, physical exhaustion and health problems ${ }^{(5)}$. Extended care period associated with the degree of dependence of the elderly can have a negative impact on the health of caregivers, as they are overloaded with daily activities that imply greater risk of psychiatric and physical morbidity ${ }^{(5-7)}$.

In this sense, caregiver health care should focus on monitoring and control of risk factors for chronic diseases, such as diabetes mellitus (DM), which is one of the major public health problems ${ }^{(8)}$. According to estimates, DM cases in Brazil reach 14.3 million $^{(9)}$. Among the elderly population, this prevalence increases with aging, affecting around $20 \%$ of the population aged 65 to 74 years, and more than 3.5 million people aged 75 years or more ${ }^{(10)}$.

Results of the National Health Survey show that female people, the elderly population, low level of school education, and low income generate greater diagnosis of DM and more access to medication and medical consultation ${ }^{(10-11)}$. These data were reported in other national studies ${ }^{(12-14)}$.

Considering the above, having a better understanding of the factors associated with the risk of developing DM among caregivers enables essential indicators for the development of health policies for the prevention and control of these diseases. Because of the important role of caregivers, their health conditions should be preserved, allowing them to provide good quality care and promote their physical health.

\section{OBJECTIVE}

Evaluate the factors associated with the risk of diabetes mellitus in older caregivers.

\section{METHOD}

\section{Ethical aspects}

The development of this study observed the ethical standards in research involving human beings. All participants signed an informed consent form before the interview. The research project was approved by the Human Research Ethics Committee of Universidade Federal de São Carlos.

\section{Study design, site and period}

This is a quantitative cross-sectional study conducted in 17 Family Health Units (FHUs) of a municipality in the State of São Paulo, from April to November 2014.

\section{Sample, inclusion criteria and exclusion criteria}

Participants were selected from lists offered by the USF teams, which contain information from homes with two or more elderly people. In total, 594 homes were visited; 26 older people were excluded due to death, 28 due to address changes, 69 were not found after three attempts, and 36 were considered fully independent according to functionality scales, resulting in 351 older caregivers interviewed. Of the 351 participants who filled the complete questionnaire, 25 were excluded because they did not accept to perform anthropometric measurements. Therefore, the final sample consisted of 326 older caregivers.

The inclusion criteria were: aged 60 years or over, enrolled in a municipal USF, and acting as the primary caregiver of a dependent elderly person ( $\geq 60$ years old) living in the same house. The Katz Index of Independence in Activities of Daily Living ${ }^{(15)}$ and the Lawton Instrumental Activities of Daily Living Scale ${ }^{(16)}$ were used to distinguish the older caregivers from dependent elderly patients. The most independent elderly person in the household was considered the caregiver.

\section{Study protocol}

A questionnaire was used to collect sociodemographic data and clinical and care information about sex, age, marital status, school education level, family income, number of people living in the same home, subjective health assessment, use of medication, degree of relationship with the elderly patient, and daily care period.

The Finnish Diabetes Risk Score (Findrisc), developed in Finland and validated by the Department of Public Health of the University of Helsinki ${ }^{(17)}$, was used to assess the risk for developing DM. So far, this instrument has not been validated in Portuguese; however, it is an easy low-cost instrument that has been used in other Brazilian studies ${ }^{(18-20)}$.

The instrument has eight variables: age ( $<45$ years, $45-54$ years, 55-64 years, >64 years), body mass index (BMI) (<25: normal, 2530: overweight, $>30$ : obesity), abdominal circumference $(<94 \mathrm{~cm}$, $94-102 \mathrm{~cm},>102 \mathrm{~cm}$ for men, and $<80 \mathrm{~cm}, 80-88 \mathrm{~cm},>88 \mathrm{~cm}$ for women), physical activity (at least 30 minutes daily: yes or no), food intake pattern (regular vegetable and/or fruit intake: every day or sometimes), use of antihypertensive (yes or no), family history of diabetes (yes or no), and history of high blood sugar (yes or no).

Findrisc possible variation is from 0 to 24 points, and one is classified according to the risk for DM development: low risk ( $<7$ points), mildly moderate (7-11 points), moderate (12-14 points), high (15-20 points), and very high (more than 20 points) ${ }^{(17)}$.

BMI was calculated using the formula: $\mathrm{BMI}=\mathrm{kg} / \mathrm{m}^{2}$, with a mechanical scale of $150 \mathrm{~kg}$ capacity. Height was measured using anthropometric inelastic tape with barefoot participants, weight equally distributed between the feet, arms down next to the body, in an upright position, with the heels together and touching the wall. Abdominal circumference was measured using a measuring 
tape in centimeters placed between the iliac crest and the last rib. The other variables were self-reported by participants.

\section{Analysis of results and statistics}

Data were analyzed in the Statistical Package for the Social Sciences (SPSS for Windows), version 22.0. Calculations were made for the descriptive analysis of data. For the assessment of the factors associated with the outcome, a multiple logistic regression analysis was performed using the stepwise forward method ${ }^{(21)}$. For the selection of the variables, univariate regression analyses were performed, adopting $\mathrm{p}<0.20$ as the critical level, and later in the multiple model, only those considered significant $(p<0.05)$ or adjusted to the risk measure by at least $10 \%$, were used.

\section{RESULTS}

Most caregivers were female (76.1\%), mean age of 69.7 years $( \pm 7.0)$, and married $(90.2 \%)$. Their mean school education level was 3.7 years $( \pm 3.4)$ with prevalence of elementary education (57.5\%). Most of them (70.2\%) lived with up to three people in the same house, their average income was BRL861.65, and $52.1 \%$ of them received one to two minimum wages.

Regarding the characteristics of care, most caregivers were the patient's spouse $(84.7 \%)$ and provided care one to four hours a day (51.5\%). In general, they self-declared their health as good (40.8\%) and satisfactory (37.4\%). Most of them were taking controlled medicines (89.3\%). Table 1 shows the characteristics of elderly caregivers.

Table 1 - Descriptive analysis of sociodemographic, clinical and care context variables of older caregivers ( $\mathrm{N}=326$ ), São Carlos, São Paulo, Brazil, 2014

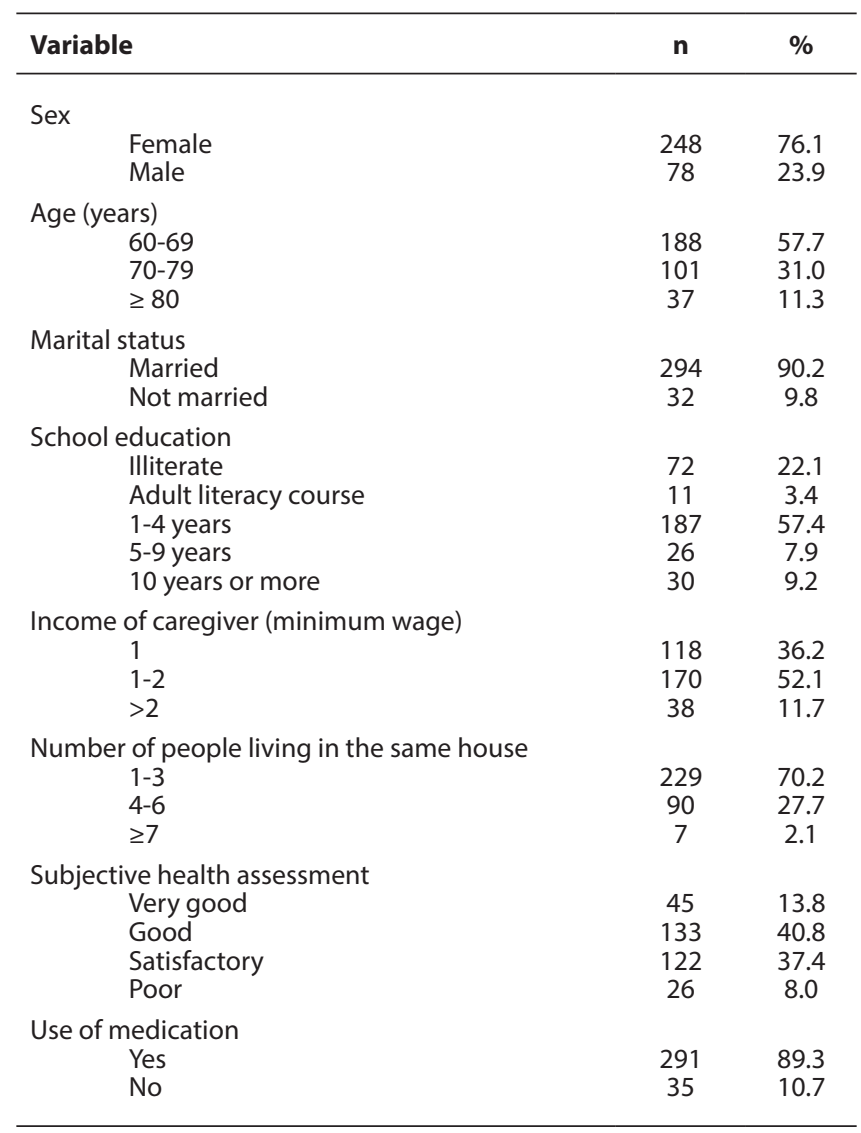

\begin{tabular}{lcc}
\hline Variable & $\mathbf{n}$ & $\%$ \\
\hline Degree of relationship & & \\
Spouse & 276 & 84.7 \\
Father/mother & 26 & 8.0 \\
Brother/sister & 11 & 3.4 \\
Father in law/mother in law & 7 & 2.1 \\
Other & 6 & 1.8 \\
Daily care period (hours) & & \\
$1-4$ & 168 & 51.5 \\
$5-9$ & 84 & 25.8 \\
$\geq 10$ & 74 & 22.7 \\
\hline
\end{tabular}

Note: SM: minimum wage corresponding to $R \$ 724.00$.

Table 2 - Distribution of caregivers according to the risk factors based on the Findrisc questionnaire ( $N=326)$, São Carlos, São Paulo, Brazil, 2014

\begin{tabular}{|c|c|c|}
\hline Variable & $\mathbf{n}$ & $\%$ \\
\hline Age & & \\
\hline $\begin{array}{l}60-64 \\
65 \text { or older }\end{array}$ & $\begin{array}{c}90 \\
236\end{array}$ & $\begin{array}{l}27.6 \\
72.4\end{array}$ \\
\hline $\begin{array}{l}\text { Body mass index } \\
\text { Normal } \\
\text { Overweight } \\
\text { Obesity }\end{array}$ & $\begin{array}{c}92 \\
118 \\
116\end{array}$ & $\begin{array}{l}28.2 \\
36.2 \\
35.6\end{array}$ \\
\hline $\begin{array}{l}\text { Abdominal circumference } \\
\qquad \begin{array}{l}M<94 / F<80 \\
M ~ 94-102 / F 80-88 \\
M>102 / F>88\end{array}\end{array}$ & $\begin{array}{c}29 \\
38 \\
259\end{array}$ & $\begin{array}{r}8.9 \\
11.7 \\
79.4\end{array}$ \\
\hline $\begin{array}{c}\text { Physical activity } \\
\text { Yes } \\
\text { No }\end{array}$ & $\begin{array}{l}198 \\
128\end{array}$ & $\begin{array}{l}60.7 \\
39.3\end{array}$ \\
\hline $\begin{array}{c}\text { Intake of fruits and vegetab } \\
\text { Yes } \\
\text { No }\end{array}$ & $\begin{array}{c}268 \\
58\end{array}$ & $\begin{array}{l}82.2 \\
17.8\end{array}$ \\
\hline $\begin{array}{c}\text { Use of antihypertensive me } \\
\text { Yes } \\
\text { No }\end{array}$ & $\begin{array}{l}221 \\
105\end{array}$ & $\begin{array}{l}67.8 \\
32.2\end{array}$ \\
\hline $\begin{array}{c}\text { Prior hyperglycemia } \\
\text { Yes } \\
\text { No }\end{array}$ & $\begin{array}{c}54 \\
272\end{array}$ & $\begin{array}{l}16.6 \\
83.4\end{array}$ \\
\hline $\begin{array}{c}\text { Family history of DM } \\
\text { Yes } \\
\text { No }\end{array}$ & $\begin{array}{l}143 \\
183\end{array}$ & $\begin{array}{l}55.2 \\
44.8\end{array}$ \\
\hline $\begin{array}{l}\text { General risk } \\
\text { Low } \\
\text { Mildly moderate } \\
\text { Moderate } \\
\text { High } \\
\text { Very high }\end{array}$ & $\begin{array}{c}15 \\
86 \\
87 \\
115 \\
23\end{array}$ & $\begin{array}{c}4.6 \\
26.4 \\
26.7 \\
35.3 \\
7.0\end{array}$ \\
\hline
\end{tabular}

Note: $D M=$ diabetes mellitus.

Table 2 shows the risk factors according to Findrisc, where $72.4 \%$ of caregivers were aged $\geq 65$ years, the minority did not practice physical activity (39.3\%) and reported no daily intake of fruits and/or vegetables (17.8\% \%). Among the caregivers, $36.2 \%$ were overweight, $52.2 \%$ had a history of DM, only $16.6 \%$ had prior hyperglycemia, and $67.8 \%$ were taking antihypertensive medication.

The Findrisc mean score was $13.5( \pm 4.1)$; therefore, considering the questionnaire categories, $35.5 \%$ presented high risk (Table 2).

Table 3 shows the results of multiple logistic regression analysis. The risk for DM was associated with the following factors: use of medication $(\mathrm{OR}=3.88)$, health assessed as satisfactory or negative $(O R=1.72)$, and being female $(O R=0.48)$. Each increase in the number of people living in the same house represents 1.25 more chances of developing DM. For caregivers, each year 
of advanced aging corresponds to 1.04 more risks for DM. All associations were controlled by income per capita (OR=1.000).

Table 3 - Final logistic regression model of variables associated with the risk of diabetes mellitus among older caregivers, São Carlos, São Paulo, Brazil, 2014

\begin{tabular}{lccc}
\hline Variables & $\boldsymbol{p}$ value & OR & $\mathbf{C l}(\mathbf{9 5} \%)$ \\
\hline Use of medication & 0.001 & 3.88 & $1.74-8.64$ \\
Self-perception of health condition as satisfactory, poor or very poor & 0.027 & 1.72 & $1.06-2.79$ \\
Being female & 0.021 & 0.48 & $0.26-0.89$ \\
Number of people who live in the same house & 0.024 & 1.25 & $1.03-1.52$ \\
Age & 0.013 & 1.04 & $1.01-1.08$ \\
Income & 0.831 & 1.00 & $1.00-1.00$
\end{tabular}

retirement pension is the only source of income for these families, with the elderly person acting as a critical provider ${ }^{(31)}$. Limited financial resources place the elderly people in a situation of social vulnerability, exposing them to the risk of sickness, pre-existing diseases or a possibility to compromise a treatment, since many elderly people use medications not always provided by the government (Brazilian Health System - SUS) ${ }^{(30-31)}$.

A poor health assessment may be related to the task of care provision. In the literature, older caregivers report fatigue, stress

\section{DISCUSSION}

The sociodemographic data and care context information are similar to those found in the national and international literature $^{(22-25)}$. The predominance of female caregivers reflects the sociocultural role of women, who are assigned care tasks. Younger elderly are more likely to have living parents requiring care than older people ${ }^{(22)}$. When caregivers are the patient's spouse, there is a relation of matrimonial obligation to take care of the spouse, since the commitment to be together in sickness and in health was assumed when they got married ${ }^{(26)}$.

Negative outcomes such as frailty, mental health problems and chronic conditions may be associated with age ${ }^{(26)}$. Brazilian studies reported more frequent DM cases among older women of low school education level ${ }^{(10-11)}$, indicating that unhealthy habits and lower levels of information can be an obstacle to health services early in the process, when seeking prevention of health complications.

Regarding the score of caregivers in the Findrisc questionnaire, one third of them presents a high risk of developing DM. A study conducted in Hungary ${ }^{(27)}$ reported mean values of 10.45 ( \pm 5.09 ) using the same questionnaire, with $41.0 \%$ of interviewees presenting increased risk of developing DM.

The factors associated with the risk of developing DM among elderly caregivers included high use of medication, poor health assessment, high number of people living in the same house, and advanced age, all of which related to income. Being female was a protective factor.

With increasing longevity, there is a trend for growing number of elderly caregivers taking care of other elderly people ${ }^{(26)}$. This study found that advanced age contributes to increased risk of developing DM. In recent years, the number of elderly people with at least one chronic disease has increased significantly ${ }^{(28)}$; besides, it constitutes a risk factor for functional disability. An epidemiological study ${ }^{(29)}$ with 286 elderly people from primary health care found that functional disability is more prevalent among older ( $\geq 75$ years old) female people who do not have a spouse. The presence of diseases such as DM, stroke and heart disease also influence the functional ability of elderly people.

Regarding the financial aspects, older caregivers are often unable to have a paid activity out of home because there is no other person available to take care of the elderly patient. This situation can impact the monthly income of the family ${ }^{(30)}$. In this sense, the and overload ${ }^{(22,32)}$, which may contribute to impairment of mental, physical and psychological well-being ${ }^{(4)}$. In this perspective, a better understanding of modifiable risk factors that influence DM is critical to support the planning of actions for the promotion, prevention and early diagnosis ${ }^{(19)}$, since health care with the disease development would require time and attention, and can be perceived negatively by a caregiver who has several tasks linked with care provision.

Given the facts above, programs to monitor the health of older caregivers should be promoted, which include variables for the development of DM risk, thus contributing to prevention or delay of DM development, with influence on associated factors.

\section{Study limitation}

This study has some limitations. It is a cross-sectional study conduct $3 \mathrm{~d}$ with a specific sample of older caregivers and, therefore, data cannot be generalized. Also, it is not possible to establish a cause-and-effect relationship. Studies of different designs in this area are certainly necessary in basic health care, especially considering the increasing number of informal older caregivers.

\section{Contributions to the area of nursing, health or public policy}

A better understanding of risk factors for the development of diabetes mellitus among older caregivers allows the definition of health goals for this population and prevention strategies for other health problems. It is a critical aspect, since the number of elderly people who provide care to other elderly people in Brazil has grown in quantity and importance. The results of this study may be a warning for health professionals indicating a timely identification of modifiable risk factors for diabetes mellitus.

\section{CONCLUSION}

This study concluded that more than one third of older caregivers present a high risk of developing DM. Therefore, being female, living with other people, using medication, having a poor health assessment are factors associated with an increase of this risk.

In this sense, intervention measures in public health are required, such as training to health professionals for the promotion of healthy habits, prevention and treatment of chronic diseases, avoiding modifiable risk factors for the development of DM. 


\section{REFERENCES}

1. Mendes TAB, Goldbaum M, Segri NJ, Barros MBA, Cesar CLC, Carandina L, et al. [Diabetes mellitus: factors associated with prevalence in the elderly, control measures and practices, and health services utilization in São Paulo, Brazil]. Cad Saúde Pública [Internet]. 2012 [cited 2017 May 25];27(6):1233-43. Available from: http://www.scielo.br/pdf/csp/v27n6/20.pdf Portuguese.

2. Tomomitsu MRSV, Perracini MR, Neri AL. [Factors associated with satisfaction with life among elderly caregivers and non-caregivers]. Ciênc Saúde Colet [Internet]. 2014 [cited 2017 May 25];19(8):3429-40. Available from: http://www.scielo.br/pdf/csc/v19n8/1413-8123csc-19-08-03429.pdf Portuguese.

3. Anjos KF, Boery RNSO, Pereira R. Quality of life of relative caregivers of elderly dependents at home. Texto Contexto Enferm [Internet]. 2014 [cited 2017 May 25];23(3):600-8. Available from: http://www.scielo.br/pdf/tce/v23n3/0104-0707-tce-23-03-00600.pdf

4. Luchesi BM, Souza EN, Gratão ACM, Gomes GAO, Inouye K, Alexandre T, et al. The evaluation of perceived stress and associated factors in elderly caregivers. Arch Gerontol Geriatr. 2016;67:7-13. doi: 10.1016/j.arcger.2016.06.017

5. Loureiro LN, Fernandes MGM, Nóbrega MML, Rodrigues RAP. [Overburden on elderly's family caregivers: association with characteristics of the elderly and care demand]. Rev Bras Enferm [Internet]. 2014 [cited 2017 May 25];67(2):222-7. Available from: http://www.scielo.br/pdf/ reben/v67n2/0034-7167-reben-67-02-0227.pdf Portuguese.

6. Stewart NJ, Morgan DG, Karunanayake CP, Wickenhauser JP, Cammer A, Minish D, et al. Rural caregivers for a family member with dementia: models of burden and distress differ for women and men. J App Gerontol [Internet]. 2014 [cited 2017 May 27];35(2):1-29. Available from: http://journals.sagepub.com/doi/pdf/10.1177/0733464813517547

7. Pereira LSM, Soares SM. [Factors influencing the quality of life of family caregivers of the elderly with dementia]. Ciênc Saúde Coletiva [Internet]. 2015 [cited 2017 May 27];20(12):3839-51. Available from: http://www.scielo.br/pdf/csc/v20n12/1413-8123-csc-20-12-3839.pdf Portuguese.

8. Karino MA, Pace AE. [Risk of complications in the feet of workers with diabetes mellitus]. Ciên Cuid Saúde [Internet]. 2012 [cited 2017 May 27];11:183-90. Available from: http://periodicos.uem.br/ojs/index.php/CiencCuidSaude/article/view/17074/pdf Portuguese.

9. International Diabetes Federation. IDF Diabetes Atlas [Internet]. 7th ed. Brussels: IDF; 2015 [cited 2017 May 27]. Available from: http://www. diabetesatlas.org/resources/2015-atlas.html

10. Iser BPM, Stopa SR, Chueiri PS, Szwarcwald CL, Malta DC, Monteiro HOC, et al. [Self-reported diabetes prevalence in Brazil: results from National Health Survey 2013]. Epidemiol Serv Saúde [Internet]. 2015 [cited 2017 May 27];24(2):305-14. Available from: http://www.scielo.br/ pdf/ress/v24n2/2237-9622-ress-24-02-00305.pdf Portuguese.

11. Malta DC, Stopa SR, Szwarcwald CL, Gomes NL, Silva Jr JB, Reis AAC. Surveillance and monitoring of major chronic diseases in Brazil National Health Survey, 2013. Rev Bras Epidemiol [Internet]. 2015 [cited 2017 May 27];18(2):3-16. Available from: http://www.scielo.br/pdf/ rbepid/v18s2/en_1980-5497-rbepid-18-s2-00003.pdf

12. Vitoi NC, Fogal AS, Nascimento CM, Franceschini SCC, Ribeiro AQ. Prevalence and associated factors of diabetes in the elderly population in Viçosa, Minas Gerais, Brazil. Rev Bras Epidemiol [Internet]. 2015 [cited 2017 May 27];18(4):953-65. Available from: http://www.scielosp.org/ pdf/rbepid/v18n4/en_1980-5497-rbepid-18-04-00953.pdf

13. Leite ES, Lubenow JAM, Moreira MRX, Martins MM, Costa IP, Silva AO. Evaluation of the impact of diabetes mellitus on the quality of life of aged people. Ciênc Cuid Saúde [Internet]. 2015 [cited 2017 May 27];14(1):822-9. Available from: http://periodicos.uem.br/ojs/index.php/ CiencCuidSaude/article/view/21353/pdf_291

14. Silva AB, Engroff P, Sgnaolin V, Ely LS, Gomes I. [Prevalence of diabetes mellitus and medication adherence in elderly of the Family Health Program in Porto Alegre]. Cad Saúde Colet [Internet]. 2016 [cited 2017 May 28];24(3):308-16. Available from: http://www.scielo.br/pdf/ cadsc/v24n3/1414-462X-cadsc-24-3-308.pdf Portuguese.

15. Lino VTS, Pereira SRM, Camacho LAB, Ribeiro Filho ST, Buksman S. [Cross-cultural adaptation of the independence in activities of Daily Living Index (Katz Index)]. Cad Saúde Pública [Internet]. 2008 [cited 2017 May 28];24(1):103-12. Available from: http://www.scielo.br/pdf/csp/ v24n1/09.pdf Portuguese.

16. Santos RL, Virtuoso Jr RL. [Reliability of the Brazilian version of the Scale of Instrumental Activities of Daily Living]. Rev Bras Psiquiatr [Internet]. 2008 [cited 2017 May 28];21(4):290-6. Available from: http://hp.unifor.br/pdfs_notitia/2974.pdf Portuguese.

17. Lindström J, Tuomilehto J. The diabetes risk score: a practical tool to predict type 2 diabetes risk. Diabetes Care [Internet]. 2003 [cited 2017 May 28];26:725-31. Available from: http://care.diabetesjournals.org/content/26/3/725.full-text.pdf

18. Araújo LO, Silva ES, Mariano JO, Moreira RC, Prezotto KH, Fernandes CAM, et al. Risk of developing diabetes mellitus in primary care health users: a cross-sectional study. Rev Gaúcha Enferm [Internet]. 2015 [cited 2017 May 28];36(4):77-83. Available from: http://www.scielo.br/pdf/ rgenf/v36n4/1983-1447-rgenf-36-04-00077.pdf

19. Bruno A, Pereira LR, Almeida HS. Evaluation of the prevalence of risk factors for development of type 2 diabetes mellitus in patients at the Unesc Clinic. Demetra [Internet]. 2014 [cited 2017 May 28];9(3):661-80. Available from: http://www.e-publicacoes.uerj.br/index.php/ demetra/article/viewFile/10659/12439

20. Marinho NBP, Vasconcelos HCA, Alencar AMPG, Almeida PC, Damasceno MMC. Risk for type 2 diabetes mellitus and associated factors. Acta Paul Enferm [Internet]. 2013 [cited 2017 May 30];26(6):569-74. Available from: http://www.scielo.br/pdf/ape/v26n6/en_10.pdf 
21. Hosmer DW, Lemeshow S. Applied logistic regression. New York: John Wiley \& Sons; 1989.

22. Fernández-Argüelles EL, Rodríguez-Mansilla J, Antunez LE, Garrido-Ardila EM, Muñoz RP. Effects of dancing on the risk of falling related factors of healthy older adults: a systematic review. Arch Gerontol Geriatr [Internet]. 2015 [cited 2017 May 30];60(1):1-8. Available from: http://www.sciencedirect.com/science/article/pii/S0167494314001824

23. Gaioli CCLO, Furegato ARF, Santos JLF. [Profile of caregivers of elderly people with Alzheimer disease associated to resilience]. Texto Contexto Enferm [Internet]. 2012 [cited 2017 May 30];21(1):150-7. Available from: http://www.scielo.br/pdf/tce/v21n1/a17v21n1.pdf Portuguese.

24. Garces SBB, Krug MR, Hasen D, Brunelli AV, Costa FTL, Rosa CB, et al. [Resilience evaluation of caregivers of elderly people with Alzheimer]. Rev Bras Geriatr Gerontol [Internet]. 2012 [cited 2017 May 30];15(2):335-52. Available from: http://www.scielo.br/pdf/rbgg/v15n2/16.pdf Portuguese.

25. Stackfleth R, Diniz MA, Fhon JRS, Vendruscolo TRP, Fabricio-Wheve SCC, Marques S, et al. Burden of work in caregivers of frail elders living at home. Acta Paul Enferm [Internet]. 2012 [cited 2017 May 30];25(5):768-74. Available from: http://www.scielo.br/pdf/ape/v25n5/en_19.pdf

26. Pereira RA, Santos EB, Fhon JRS, Marques S, Rodrigues RAP. Burden on caregivers of elderly victims of cerebrovascular accident. Rev Esc Enferm USP [Internet]. 2013 [cited 2017 May 30];47(1):185-92. Available from: http://www.scielo.br/pdf/reeusp/v47n1/en_a23v47n1.pdf

27. Winkler G, Hidvégi T, Vándorfi G, Balogh S, Jermendy G. Prevalence of undiagnosed abnormal glucose tolerance in adult patients cared for by general practitioners in Hungary. Results of a risk-stratified screening based on Findrisc questionnaire. Med Sci Monit [Internet]. 2013 [cited 2017 May 30];19:67-72. Available from: https://www.ncbi.n/m.nih.gov/pmc/articles/PMC3629009/pdf/medscimonit-19-67.pdf

28. Neri AL, Yassuda MS, Araújo LF, Eulálio MC, Cabral BE, Siqueira MEC, et al. [Methodology and social, demographic, cognitive, and frailty profiles of community-dwelling elderly from seven Brazilian cities: the FIBRA Study]. Cad Saúde Pública [Internet]. 2013 [cited 2017 May 30];29(4):778-92. Available from: http://www.scielo.br/pdf/csp/v29n4/15.pdf Portuguese.

29. Barbosa BR, Almeida JM, Barbosa MR, Rossi-Barbosa LAR. [Evaluation of the functional capacity of the elderly and factors associated with disability]. Ciênc Saúde Coletiva [Internet]. 2014 [cited 2017 May 30];19(8):3317-25. Available from: http://www.scielo.br/pdf/csc/ v19n8/1413-8123-csc-19-08-03317.pdf Portuguese.

30. Santos GS, Cunha ICKO. Perfil sociodemográfico de cuidadores familiares de idosos residentes em uma área de abrangência da Estratégia Saúde da Família no município de São Paulo. Saúde Colet [Internet]. 2013 [cited 2017 May 30];10(60):47-53. Available from: http://www. redalyc.org/articulo.oa?id=84228212008.

31. Antunes JFS, Okuno MFP, Lopes MCBT, Campanharo CRV, Batista REA. Frailty assessment of elderly hospitalized at an emergency service of a university hospital. Cogitare Enferm [Internet]. 2015 [cited 2017 May 30];20(2):266-73. Available from: http://docs.bvsalud.org/ biblioref/2016/08/1254/39928-157216-1-pb.pdf

32. Gratão ACM, Talmelli LFS, Figueiredo LC, Rosset I, Freitas CP, Rodrigues RAP. Functional dependency of older individuals and caregiver burden. Rev Esc Enferm USP [Internet]. 2013 [cited 2017 May 30];47(1):134-41. Available from: http://www.scielo.br/pdf/reeusp/v47n1/ en_a17v47n1.pdf/ 